of scientific and technological manpower. This is the conclusion of a working group on Engineering Training and the Requirements of Industry set up last year by Sir Willis Jackson of the Ministry of Technology's Committee on Manpower Resources for Science and Technology. In its report, the group calls for close co-operation between educationalists and industry to establish a programme of "matching sections" of formal education and training. By exposing engineering students to the intellectual and practical problems of manufacturing industries, they hope to maintain the interest and enthusiasm of those students who might otherwise go into research.

To co-ordinate these "matching sections", the group calls for centres of product technology, established by collaboration between an educational institution and one or more industrial units, with teaching at the former and the industrial plants used as full-scale demonstration laboratories. It envisages a training programme of approximately one or two years that would begin when a graduate enters a firm. At this time he would be exposed to possible jobs and specializations, begin to learn the principles of manufacturing engineering, and take part in a group project to expose him to the practical problems he will face. On choosing his first job and gaining some experience, he would enter a course at the centre in either product technology, manufacturing technology, or special techniques. He would then return to his firm for more supervised training.

\section{Swings and Roundabouts}

The annual report of the British Post Office contains in microcosm the contemporary history of the balance between the different means of communication between people. On one hand, there is the traditional postal service which was introduced in Britain in 1840 , with the Penny Post. On the other hand, there is the telephone system. The first of these services has had, in recent years, a tendency to run at a loss. As good luck and increased charges would have it, 1965-66 was not too bad a year. The postal services actually made a small profit-something like $\mathfrak{£} 0.9$ million out of a total turnover of $£ 318$ million. But nobody is very hopeful about the years ahead. Already a further round of price increases has been announced.

By contrast, the telephone service is booming. In the course of a year, charges to the British public actually declined, chiefly because of the introduction of automatic dialling, yet the Post Office made a surplus of roughly 10 per cent on its telephone business. Demand from the public is at the same time growing quickly. Even local calls increased by 8 per cent in the course of a year. Trunk calls went up by 14 per cent and overseas calls by no less than 21 per cent, partly, no doubt, because of the arrival of satellite communications across the Atlantic and facilities for dialling direct to the mainland of Europe. All this, of course, is entirely to be expected. Telephones will keep on winning over posts. One practical question is whether those in charge of the Post Office should anticipate the future by weighting the odds even more heavily against the posts than the realities of handling pieces of paper entail. The second question, not quite so practical, is what will happen decades hence to all those letters written not for people now alive but for posterity.

\section{Parliament in Britain}

REPLYING on July 12 to an adjournment debate on the training of teachers, Mr. G. Roberts, Minister of State, Department of Education and Science, said that, since the announcement last year of the intention to establish departments of education in suitably located technical colleges, the local education authorities in Inner London, Birmingham, Manchester, Nottingham and Sunderland had been consulted. All had expressed a desire to participate and were preparing detailed proposals. It was hoped that the new departments of education would take their first students in the academic year 1967-68. The departments might be expected to attract to teacher training some technical college students who would not otherwise have thought of taking up teaching, and $\mathrm{Mr}$. Roberts emphasized that the departments would provide courses comparable with the best afforded by the traditional college of education and the university departments of education. Initially, it was intended that the new departments should cater essentially for students taking a 3-year certificate course leading to qualified teacher status, but no doubt in due course the departments would introduce also 4-year courses leading both to degree and to professional teaching qualifications. Departments would start with about 100 students and rise to 250 to 300 . For some years their main emphasis would be on training teachers for the primary schools.

REPLYING for the Government in a debate on July 8 on computers in universities, Mr. G. Roberts emphasized that the programme of the Flowers Group for new university computers, which the Government had approved, would provide for an integrated system. There would be regional centres in London, Manchester and Edinburgh. Of the 28 universities fitting into the Flowers programme, nine had delivery dates for their machines varying from July 1966 to the end of the year. Pending the establishment of the Computer Board, the membership and functions of which would be announced shortly, the University Grants Committee had made an interim arrangement for considering the most urgent cases and planning orders. Approval had already been given, at a cost of $£ 4.8$ million in the period 1966-69, for upgrading the $K D F 9$ computers at the seven universities recommended by the Flowers Group and for new installations for 21 other universities.

IN a written reply to a question in the House of Commons on July 20 regarding liaison with other countries on the courses of hurricanes, the UnderSecretary of State for Defence for the Royal Air Force, Mr. M. Rees, stated that the Meteorological Office kept in touch with other countries on hurricane research. There was liaison with the Hong Kong Meteorological Office and also with the United States National Hurricane Research Laboratory and other American weather agencies. In the near future, cloud photographs would be received at Muharraq, Gan and Singapore direct from U.S. weather satellites and would help to provide warning of hurricanes in the Indian Ocean and Far East areas. The Meteorological Office also participated in a recent North Atlantic Treaty Organization conference on cloud dynamics at which the problem of hurricanes was discussed. 